\title{
Seed Bank from Soll of Coffee Plantations Associated with Grevillea TREes ${ }^{1}$
}

\author{
Banco de Sementes do Solo Proveniente de Cafezais Arborizados com Grevílea
}

\author{
SANTOS, M.A.F. ${ }^{2}$, MATSMOTO, S.N. ${ }^{3}$, CESÁR, F.R.C.F. ${ }^{2}$, BONFIM, J.A. ${ }^{2}$, ARAUJO, G.S..$^{2}$ e \\ VIANA, A.E.S. ${ }^{3}$
}

\begin{abstract}
This study aimed to study the composition and dynamics of seed bank from soil of coffee plantations associated with grevilea trees in the experimental fields of the Southwest Bahia State University, on Vitória da Conquista campus. The experiments were carried out from September 2006 to May 2007. The coffee trees (Coffea arabica) were sown at three $x$ one $m$ spacing, associated with grevillea trees (Grevillea robusta) and maintained at densities of 277, 139, 123, 69, 62 and 31 plants ha-1, under direct sunlight. One hundred grams of soil were taken from each treatment with four repetitions and later identified and counted with a $10 x$ magnifying glass. To determine seedling emergence, four soil samples of $1000 \mathrm{~g}$ were collected from each experimental field and transported to the greenhouse. Seedling emergence was observed by counts after 15, 30 and 45 days. The experimental design was randomized blocks of seven treatments (soil from different tree densities) and four replicates; the experimental unit consisted of a plastic tray $(0,30$ $\times 0.22 \times 0.06 \mathrm{~m}$ ) containing $1.000 \mathrm{~g}$ of soil. The variables utilized to characterize the bank and its dynamics were: relative frequency, relative density, relative abundance, importance index and species diversity (Shannon-Weaverindex).Increased number of monocotyledon seeds and sprouts were verified in the treatments maintained under full sunlight.
\end{abstract}

Keywords: Coffea arabica, Grevillea robusta, phytosociology.

\begin{abstract}
RESUMO - Com o objetivo de estudar a composição e a dinâmica do banco de sementes provenientes de solos de cafezais arborizados com grevíleas, desenvolveu-se um ensaio no campo experimental da Universidade Estadual do Sudoeste da Bahia, no campus de Vitória da Conquista. Os cafeeiros (Coffea arabica) foram dispostos em espaçamento de $3 \times 1 \mathrm{~m}$, associados a grevileas (Grevillea robusta) mantidas em densidades de 277, 139, 123, 69, 62 e 31 plantas ha ${ }^{-1}$, e a pleno sol, no período de setembro de 2006 a maio de 2007. Para avaliação do número de sementes, foram retirados $100 \mathrm{~g}$ de solo de cada amostra composta, com quatro repetições, que foram identificadas e contadas posteriormente, com auxílio de uma lupa de 10x de aumento. Para determinação da emergência de plântulas, quatro amostras de 1.000 g de solo de cada campo experimental foram levadas para casa de vegetação, sendo analisada a emergência de plântulas, a partir de contagens realizadas aos 15, 30 e 45 dias após a implantação. O delineamento experimental utilizado foi o de blocos casualizados, constando de sete tratamentos (solos provenientes de diferentes densidades de árvores) e quatro repetições; a parcela experimental foi constituída por uma bandeja plástica $(30 \times 22 \times 6 \mathrm{~cm})$ contendo $1.000 \mathrm{~g}$ de solo. As variáveis utilizadas para caracterização do banco e sua dinâmica foram: freqüência relativa, densidade relativa, abundância relativa, indice de valor de importância e diversidade de espécies (indice de Shannon-Weaver). Foram verificados maiores indices para sementes e plântulas monocotiledôneas nos tratamentos mantidos a pleno sol.
\end{abstract}

Palavras-chave: Coffea arabica, Grevillea robusta, fitossociologia.

1 Recebido para publicação em 29.2.2008 e na forma revisada em 17.7.2008.

2 Graduandos de Engenharia Agronômica da Universidade Estadual do Sudoeste da Bahia; ${ }^{3}$ Eng ${ }^{-}-$Agr ${ }^{\circ}$, D. Sc., Professor Titular, Dep. de Fitotecnia e Zootecnia, Universidade Estadual do Sudoeste da Bahia, 45083-900, Vitória da Conquista-BA. 


\section{INTRODUCTION}

The occurrence of weeds is one of the factors causing great impact on agricultural production, being directly related to reduced productivity. The great diversity, frequency and abundance that characterize tropical ecosystems demand a complex understanding of the inter-relations among Brazilian regions. Therefore, it is necessary to construct an underlying knowledge of the eco-physiology of species composing plant production systems.

For traditional monocultures, during installation periods, a reduced growth potential and use of cultivated plants results in high availability of abiotic factors, such as water, nutrients and light radiance incidence. Such circumstances favor the establishment of spontaneous plants, which can interfere negatively on the vigor and productivity of cultures. In agro-forestry systems, species arrangement maximizes the utilization of these resources and promotes culture development, restraining competition between the cultivated species and the weeds (Souza, 2003). Various studies recorded weed reduction in coffee plantations set up under agro-forestry systems (Nestel \& Altieri, 1992). According to Staver et al. (2001), spontaneous plant biomass reduction results from the interception of light radiation by tree canopy and coffee plantations, as well as by the cumulative effect of shading. According to Silva et al. (2006), the introduction of trees in coffee plantations promotes solar radiation restriction, inhibits infestation and alters weed population composition.

The seed bank in the soil provides important information on environmental conditions and cultural practices previously adopted, as well as being a significant factor to be considered in the evaluation of future infestations. Its dynamics is directly influenced by the abundance of seeds along time (Severino, 2001). Information on the seed bank of weeds in soil, taking its dynamics into account, can directly assist in making decisions regarding integrated practices to control and manage weeds. Adequate management can result in greater overall system balance and eventually lead to less

Planta Daninha, Viçosa-MG, v. 26, n. 4, p. 726-733, 2008 aggression to the agricultural environment (Lacerda, 2003)

The objective of this research is to study weed seed bank dynamics in coffee plantations associated with grevilea trees at different densities, in Vitória da Conquista, Bahia.

\section{MATERIALS AND METHODS}

The experiment was conducted in the agricultural field of the Southwest State University of Bahia, Vitória da Conquista campus. The municipality is located $40^{\circ} 50$ $53^{\prime \prime W}$ and $14^{\circ} 5053^{\prime \prime} \mathrm{S}$, at 923 meters above sea level, in the semi-arid region of the State of Bahia, characterized by low rainfall and periodic droughts. The observations were carried out in seven fields with the coffee plants arranged in $3 \times 1 \mathrm{~m}$ spacing, under direct sunlight and associated with grevillea trees planted at densities of 277, 139, 123, 69, 62 and 31 plants ha- ${ }^{-1}$, corresponding to a mean height value of respectively 9.60, 8.90, 8.40, $8.80,8.40$ and $7.60 \mathrm{~m}$.

The soil samples were collected on September 01, 2006, October 15, 2006, December 02, 2006, January 20, 2007, March 23, 2007 and May 28, 2007, and removed with a $9 \mathrm{~cm}$ diameter bore in between the coffee lines. Ten samples were collected at a depth of $0-10 \mathrm{~cm}$, homogenized, placed in plastic bags and taken to the laboratory for mass determination. For emergence evaluation, four simple samples of equal mass (1000 g each) were taken from each compound sample and placed in non drainable plastic trays of $0.30 \mathrm{x}$ $0.22 \times 0.06 \mathrm{~m}$, forming a layer of soil approximately $2 \mathrm{~cm}$ thick, labeled, taken to the greenhouse and watered daily.

The evaluations were performed at 15, 30 and 45 days after implanting in the greenhouse. After emergence, the plantlets were identified and classified by species according to Lorenzi (1994) and removed from the tray. When questions arose in relation to a particular seedling's taxonomic classification, this seedling was removed from the plastic tray and placed in another recipient to reach a size at which it could be identified.

In order to evaluate number of seeds, $100 \mathrm{~g}$ of soil were collected from each compound sample, with four replicates. These sub- 
samples were added to a solution of $200 \mathrm{ml}$ of de-ionized water, $10 \mathrm{~g}$ of sodium bicarbonate $\left(\mathrm{NaHCO}_{3}\right)$ and $25 \mathrm{~g}$ of hepta-hydrated magnesium sulfate $\left(\mathrm{MgSO}_{4} \cdot 7 \mathrm{H}_{2} \mathrm{O}\right)$, which permitted flowing of the organic part of the sample. Matter was then removed and set to dry in the shade on a paper filter; the seeds were sorted out with the help of a $10 x$ magnifying glass and later identified.

For analysis of the seed bank communities, the following phytosociological variables were calculated: relative frequency (evaluation of species distribution in the plots evaluated); relative density (quantity of seeds and plantlets of each species per unit of area); relative abundance (species concentration in the evaluated area), importance value index (indicating the most important species in a given study area) and species diversity index (Shannon-Weaver).

The statistical analysis used to compare the mean values of the treatments was established by the $\mathrm{T}$ test, at $5 \%$ probability, considering the six data collection times as replications. In the study on diversity, the adjustment of models considered biological behavior, analysis of variance and coefficient of regression, at $10 \%$ probability.

\section{RESULTS AND DISCUSSION}

Twenty-eight species were identified when test separation and identification of seeds in soil from coffee plantations with trees were conducted (Table 1). Among the identified species, seven were classified as monocotyledonon and distributed in the Poaceae and Comelineaceae families; twentyone species were classified as dicotyledons, being grouped in 10 families. For seedling emergence in the greenhouse, twenty-seven species were identified (Table 2), being seven monocots and twenty dicotyledons and the species classified as monocotyledon were from the Poaceae family. In studies on adult weeds in recently destroyed salt water marsh forest, Sá (1996), observed similar behavior, indicating the Poaceae and Asteraceae families among the most frequent. In pasture fields, Buselato \& Bueno (1981) classified the monocotyledon Poaceae and Cyperaceae and the dicotyledons Asteraceae as the most abundant families, with the remaining families being represented by less than three species. Souza et al. (2006) observed that a control band of Brachiaria decumbens within a $100 \mathrm{~cm}$ width on each side of coffee plantation line caused reduction of initial and productivity. Ronchi \& Silva (2006) verified a severe reduction of relative contents of macro and micronutrients when young coffee plants were submited to interference of Bidens pilosa, Commelina diffusa and Leonurus siribicus. the effects in a reduction of root system were observed by Ronchi et al. (2006) when coffee plants were cultivated in competition with Leonurus sibiricus, Nicandra physaloides and Richardia brasiliensis. In the present study, the species of greatest occurrence were Brachiaria sp. (Poaceae) in the seed test, and Portulaca oleracea (Asteraceae) in the seedling emergence test. According to Favreto \& Medeiros (2006), physical characteristics of soil related to infrequent revolving practices during soil preparation were related to decreased emergence of Brachiaria plataginea seedlings and increased emergence of Sida rhombifolia. In the aforementioned study, other edaphic variables, such as organic matter, $\mathrm{pH}$ and $\mathrm{P}$ quantity, also had significant effects on the composition of the seed bank evaluated in cultivation areas in a natural field in the low central region of Rio Grande do Sul. Correlation between bank seeds and tht aboveground weed vegetation must be studied to understanding how biotic and abiotic components act in this cycle. Isaac \& Guimarães (2008) observed relation between seed bank and posterior aboveground weed in annual crop fields under no-till and tillage systems only for Amaranthus deflexus and Eleusine indica. For A. deflexus, the correlation was significant in both cultivation systems, while for E. indica, only under no-till.

There was no difference between shaded and sunlight fields when relative frequency was evaluated in a test for monocotyledon seeds, indicative of high dispersion capacity for seeds of this species. Higher levels of relative density and relative abundance of monocotyledon species were observed when testing seeds from soil of coffee plantation field maintained under direct sunlight. In discriminating the behavior of the monocot 
Table 1 - Relative frequency (FRR), relative density (DENR), relative abundance (ABUR) and importance of value index (IVI), of seeds from soil of coffee plantations associated with grevillea trees $\left(277,139,123,69,62,31\right.$, plants ha $\left.{ }^{1}\right)$ at full sunlight. Vitória da Conquista, Bahia. 2007

\begin{tabular}{|c|c|c|c|c|c|c|c|c|c|}
\hline \multirow{2}{*}{ Specie } & \multirow{2}{*}{ Common name } & \multicolumn{2}{|c|}{ FRR } & \multicolumn{2}{|c|}{ DENR } & \multicolumn{2}{|c|}{ ABUR } & \multicolumn{2}{|c|}{ IVI } \\
\hline & & Shade & Sun & Shade & Sun & Shade & Sun & Shade & Sun \\
\hline \multicolumn{10}{|l|}{ Monocotyledons } \\
\hline \multicolumn{10}{|l|}{ Poaceae } \\
\hline Brachiaria sp. & Braquiária & 10,82 & 9,56 & 32,85 & 49,55 & 29,54 & 45,65 & 73,21 & 104,76 \\
\hline Panicum maximum Jacq. & Capim-colonião & 2,38 & 4,37 & 0,55 & 1,55 & 1,06 & 2,12 & 3,99 & 8,04 \\
\hline $\begin{array}{l}\text { Rhynchelitrum repens (Wild.) } \\
\text { Hubb. }\end{array}$ & Capim-favorito & 4,91 & 6,92 & 1,49 & 2,24 & 2,29 & 2,31 & 8,69 & 11,47 \\
\hline $\begin{array}{l}\text { Setaria geniculata (Lam.) } \\
\text { Beauv. }\end{array}$ & Capim-rabo-de-gato & 4,21 & 5,21 & 1,20 & 1,50 & 1,94 & 2,76 & 7,35 & 9,47 \\
\hline Cenchus echinatus L. & Carrapicho & 0,60 & 0,00 & 0,12 & 0,00 & 0,29 & 0,00 & 1,01 & 0,00 \\
\hline Eleusine indica (L.) Gertn. & Pé-de-galinha & 0,79 & 1,57 & 0,43 & 0,07 & 1,60 & 0,26 & 2,82 & 1,90 \\
\hline \multicolumn{10}{|l|}{ Commelinaceae } \\
\hline Commelina benghalensis $\mathrm{L}$. & Trapoeraba & 4,24 & 5,50 & 1,03 & 0,87 & 1,76 & 1,41 & 7,03 & 7,78 \\
\hline \multicolumn{2}{|l|}{ Total Monocotyledons } & 27,95A & 33,13A & 47,67B & $55,78 \mathrm{~A}$ & 38,48B & 54,51A & $104,10 \mathrm{~B}$ & $143,42 A$ \\
\hline \multicolumn{10}{|l|}{ Dicotyledons } \\
\hline \multicolumn{10}{|l|}{ Asteraceae } \\
\hline Bidens pilosa $\mathrm{L}$. & Picão-preto & 0,72 & 3,07 & 0,13 & 0,78 & 0,40 & 1,28 & 1,25 & 5,13 \\
\hline Blainvillea latifolia (L.f.) DC. & Picão-grande & 5,18 & 8,36 & 1,38 & 5,11 & 2,00 & 4,95 & 8,56 & 18,42 \\
\hline Emilia sanchifolia $($ L.) DC. & Falsa-serralha & 8,72 & 8,79 & 5,29 & 4,51 & 5,36 & 4,45 & 19,37 & 17,75 \\
\hline Gnaphalium sp. & Marcela & 1,19 & 0,42 & 0,18 & 0,05 & 0,78 & 0,19 & 2,15 & 0,66 \\
\hline Conyza sp. & Buva & 1,77 & 0,39 & 0,36 & 0,06 & 0,79 & 0,20 & 2,92 & 0,65 \\
\hline Ageratum conyzoides $\mathrm{L}$. & Mentrasto & 4,22 & 6,27 & 1,30 & 2,81 & 1,83 & 3,53 & 7,35 & 12,61 \\
\hline Synedrellpsis grisebachii & Agrião-do-pasto & 0,58 & 0,86 & 0,11 & 0,22 & 0,24 & 0,39 & 0,93 & 1,47 \\
\hline Acanthospermum hispidum & $\begin{array}{l}\text { Carrapicho-de- } \\
\text { carneiro }\end{array}$ & 0,32 & 0,42 & 0,02 & 0,05 & 0,09 & 0,00 & 0,33 & 0,47 \\
\hline \multicolumn{10}{|l|}{ Malvaceae } \\
\hline Sida sp. & Guanxuma & 4,61 & 1,87 & 1,22 & 0,42 & 1,89 & 1,05 & 7,72 & 3,34 \\
\hline Pavonia cancellata Cav. & Pavonia & 0,29 & 0,35 & 0,04 & 0,07 & 0,00 & 0,26 & 0,33 & 0,68 \\
\hline \multicolumn{10}{|l|}{ Amaranthaceae } \\
\hline Amaranthus sp. L. & Caruru & 10,50 & 8,36 & 11,75 & 2,88 & 10,73 & 3,07 & 32,98 & 14,31 \\
\hline $\begin{array}{l}\text { Alternanthera brasilianaI (L.) } \\
\text { O. Kuntze }\end{array}$ & Perpétua & 0,35 & 0,35 & 0,07 & 0,07 & 0,24 & 0,26 & 0,66 & 0,68 \\
\hline \multicolumn{10}{|l|}{ Portulacaceae } \\
\hline Portulaca oleraceae L. & Beldroega & 10,83 & 9,57 & 17,09 & 10,60 & 15,35 & 9,56 & 43,27 & 29,74 \\
\hline $\begin{array}{l}\text { Chamaesyce prostata (Ait.) } \\
\text { Small. }\end{array}$ & Quebra-pedra & 0,00 & 0,57 & 0,00 & 0,09 & 0,00 & 0,31 & 0,00 & 0,98 \\
\hline $\begin{array}{l}\text { Chamaesyce hyssopifolia (L.) } \\
\text { Small. }\end{array}$ & Erva-de-andorinha & 0,13 & 0,00 & 0,02 & 0,00 & 0,07 & 0,00 & 0,22 & 0,00 \\
\hline Eufhorbia brasiliensis Lam. & Capim-tapete & 0,23 & 0,00 & 0,05 & 0,00 & 0,00 & 0,19 & 0,41 & 0,19 \\
\hline \multicolumn{10}{|l|}{ Chenopodiaceae } \\
\hline Chenopodium caricatum Lam. & Anserina-rendada & 10,31 & 8,04 & 10,08 & 6,19 & 9,22 & 6,38 & 29,60 & 20,61 \\
\hline \multicolumn{10}{|l|}{ Aizoaceae } \\
\hline Mollungo verticillata $\mathrm{L}$. & Capim-tapete & 10,73 & 8,35 & 12,74 & 10,27 & 11,61 & 9,26 & 35,08 & 27,88 \\
\hline \multicolumn{10}{|l|}{ Passifloraceae } \\
\hline Passiflora sp. & Passiun-fruit & 0,36 & 0,00 & 0,07 & 0,00 & 0,23 & 0,00 & 0,66 & 0,00 \\
\hline \multicolumn{10}{|l|}{ Rubiaceae } \\
\hline Coffea arabica $\mathrm{L}$. & Coffee & 0,16 & 0,00 & 0,03 & 0,00 & 0,04 & 0,00 & 0,23 & 0,00 \\
\hline \multicolumn{10}{|l|}{ Brassicaceae } \\
\hline Lopidium ruderale L. & Mentrasto & 0,78 & 0,42 & 0,09 & 0,05 & 0,31 & 0,19 & 1,18 & 0,66 \\
\hline \multicolumn{2}{|l|}{ Total of Dicotyledons } & $73,05 \mathrm{~A}$ & $66,87 \mathrm{~A}$ & $62,33 \mathrm{~A}$ & $44,22 B$ & $61,52 \mathrm{~A}$ & 45,49B & $195,90 \mathrm{~A}$ & $156,58 \mathrm{~B}$ \\
\hline Total & & 100 & 100 & 100 & 100 & 100 & 100 & 300 & 300 \\
\hline
\end{tabular}


Table 2 - Relative frequency (FRR), relative density (DENR), relative abundance (ABUR) and importance of value index (IVI), of seedlings from seed bank of weeds, from coffee plantations associated with grevillea trees $\left(277,139,123,69,62,31\right.$, plants ha $\left.^{-1}\right)$ at full sunlight. Vitória da Conquista, Bahia. 2007

\begin{tabular}{|c|c|c|c|c|c|c|c|c|c|}
\hline \multirow{2}{*}{ Specie } & \multirow{2}{*}{ Common name } & \multicolumn{2}{|c|}{ FRR } & \multicolumn{2}{|c|}{ DENR } & \multicolumn{2}{|c|}{ ABUR } & \multicolumn{2}{|c|}{ IVI } \\
\hline & & Shade & Sun & Shade & Sun & Shade & Sun & Shade & Sun \\
\hline \multicolumn{10}{|l|}{ Monocotyledons } \\
\hline \multicolumn{10}{|l|}{ Poaceae } \\
\hline Brachiaria sp. & Capim-braquiária & 11,20 & 8,27 & 13,75 & 9,46 & 12,11 & 10,05 & 37,06 & 27,78 \\
\hline Eleusine indica (L.) Gaert. & $\begin{array}{l}\text { Capim-pé-de- } \\
\text { galinha }\end{array}$ & 4,06 & 10,46 & 1,54 & 5,50 & 2,54 & 5,62 & 8,14 & 21,58 \\
\hline Panicum maximum Jacq. & Capim-colonião & 1,75 & 3,37 & 0,64 & 1,11 & 1,06 & 1,59 & 3,45 & 6,07 \\
\hline $\begin{array}{l}\text { Rhynchelitrum repens (Willd.) } \\
\text { Hubb. }\end{array}$ & Capim-favorito & 9,44 & 8,06 & 4,95 & 7,72 & 5,31 & 6,48 & 19,70 & 22,23 \\
\hline Setaria geniculata (Lam.) & Capim-rabo-de-gato & 0,48 & 1,70 & 0,20 & 0,37 & 0,65 & 0,92 & 1,33 & 2,99 \\
\hline Cenchus echinatus L. & Carrapicho & 0,78 & 0,45 & 0,31 & 0,14 & 0,89 & 0,33 & 1,98 & 0,92 \\
\hline \multicolumn{10}{|l|}{ Commelinaceae } \\
\hline Commelina benghalensis & Trapoeraba & 2,28 & 1,25 & 0,64 & 0,21 & 1,05 & 0,53 & 3,97 & 1,99 \\
\hline \multicolumn{2}{|l|}{ Total of Monocotyledons } & 29,99A & 33,56A & $22,03 \mathrm{~A}$ & 24,51A & $23,61 A$ & $25,49 \mathrm{~A}$ & $75,63 \mathrm{~A}$ & $83,56 \mathrm{~A}$ \\
\hline \multicolumn{10}{|l|}{ Dicotyledonous } \\
\hline \multicolumn{10}{|l|}{ Asteraceae } \\
\hline Bidens pilosa $\mathrm{L}$. & Picão-preto & 1,14 & 5,54 & 0,31 & 2,36 & 0,94 & 3,40 & 2,39 & 11,14 \\
\hline Blainvillea latifolia (L.f.) & Picão-branco & 5,04 & 5,45 & 1,88 & 1,91 & 2,62 & 2,54 & 9,54 & 9,9 \\
\hline Emilia sonchifolia $\mathrm{L}$. & Falsa-serralha & 7,55 & 6,19 & 2,59 & 3,52 & 3,39 & 4,55 & 13,53 & 14,26 \\
\hline Gnaphalium sp. & Marcela & 4,15 & 2,67 & 8,77 & 10,93 & 8,67 & 12,07 & 21,59 & 25,67 \\
\hline Conyza spp. & Buva & 0,60 & 0,00 & 0,50 & 0,00 & 0,87 & 0,00 & 1,97 & 0,00 \\
\hline Ageratum conyzoides $\mathrm{L}$. & Picão-roxo & 5,09 & 5,40 & 2,54 & 4,27 & 2,88 & 5,65 & 10,51 & 15,32 \\
\hline Synedrellopsis grisebachii & Agrião-do-pasto & 0,18 & 3,72 & 0,04 & 2,56 & 0,09 & 2,35 & 0,31 & 8,63 \\
\hline Sonchus oleraceus L. & Erva-gorda & 0,15 & 0,00 & 0,07 & 0,00 & 0,17 & 0,00 & 0,39 & 0,00 \\
\hline Acanthospermum australe & Carrapicho-rasteiro & 0,06 & 0,00 & 0,02 & 0,00 & 0,06 & 0,00 & 0,14 & 0,00 \\
\hline \multicolumn{10}{|l|}{ Malvaceae } \\
\hline Pavonia concellata $\mathrm{L}$. & Pavonia & 0,99 & 1,52 & 3,70 & 0,18 & 0,93 & 0,88 & 5,62 & 2,58 \\
\hline Sida sp. & Ganxuma & 6,54 & 5,64 & 3,01 & 2,62 & 4,15 & 3,79 & 13,70 & 12,05 \\
\hline \multicolumn{10}{|l|}{ Amaranthaceae } \\
\hline Amaranthus $\mathrm{sp}$. & Caruru & 6,11 & 3,68 & 7,42 & 1,37 & 8,06 & 1,73 & 21,59 & 6,78 \\
\hline Alternanthera brasiliana & Perpétua & 0,14 & 0,00 & 0,02 & 0,04 & 0,00 & 0,00 & 0,16 & 0,04 \\
\hline \multicolumn{10}{|l|}{ Portulacaceae } \\
\hline Portulaca oleracea $\mathrm{L}$. & Beldroega & 16,67 & 15,89 & 35,03 & 36,13 & 27,13 & 25,89 & 78,83 & 77,91 \\
\hline \multicolumn{10}{|l|}{ Euforbiaceae } \\
\hline Phyllanthus sp. & Quebra-pedra & 0,33 & 1,25 & 0,11 & 0,21 & 0,36 & 0,53 & 0,80 & 1,99 \\
\hline \multicolumn{10}{|l|}{ Chenopodiaceae } \\
\hline Chenopodium caricatum & Anserina-rendada & 9,26 & 6,69 & 11,27 & 7,98 & 11,41 & 9,07 & 31,94 & 23,74 \\
\hline \multicolumn{10}{|l|}{ Aizoaceae } \\
\hline Mollugo verticillata $\mathrm{L}$. & Capim-tapete & 4,89 & 2,14 & 3,70 & 1,33 & 4,05 & 1,72 & 12,64 & 5,19 \\
\hline \multicolumn{10}{|l|}{ Brassicaceae } \\
\hline Lepidium ruderale L. & Mentrusto & 0,95 & 0,65 & 0,31 & 0,08 & 0,37 & 0,16 & 1,63 & 0,89 \\
\hline \multicolumn{10}{|l|}{ Oxalidaceae } \\
\hline Oxalis latifolia Kunth & Trevinho & 0,12 & 0,00 & 0,02 & 0,00 & 0,04 & 0,00 & 0,18 & 0,00 \\
\hline \multicolumn{10}{|l|}{ Convolvullaceae } \\
\hline Dichondra repens & Orelha-de-gato & 0,05 & 0,00 & 0,01 & 0,06 & 0,03 & 0,33 & 0,09 & 0,39 \\
\hline Total of Dicotyledonous & & $70,01 \mathrm{~A}$ & $66,44 \mathrm{~A}$ & $77,97 \mathrm{~A}$ & $75,49 \mathrm{~A}$ & $75,39 \mathrm{~A}$ & $74,51 \mathrm{~A}$ & $231,17 \mathrm{~A}$ & $222,09 A$ \\
\hline Total & & 100 & 100 & 100 & 100 & 100 & 100 & 100 & 100 \\
\hline
\end{tabular}


species, Poaceae of the genus Brachiaria sp. and Rhynchelitrum repens were found to represent the main constituents of the population indexes in the study. The same was observed for emergence, with a high occurrence of the species Eleusine indica. There was a lower range of difference in monocotyledon species, in relation to shaded ambient and direct sunlight when evaluating the emergence of seedlings, compared to the results obtained for seed population (Tables 1 and 2). Management practices and weed architecture may have caused determining factors for this behavior. The use of a tractor mower resulted in cutting the larger weeds, inducing abscission and dispersion of immature seeds (with low germination capacity due to physiological immaturity) in the soil. However, this type of mechanical control was not effective for the species with a less erect, stronger port, like Portulaca oleracea and Mollugo verticillata, resulting in complete maturing of its seeds.

Coelho et al. (2004) conducted studies on coffee plantations kept under three cultivation systems. For seedling emergence under greenhouse conditions, there was a greater occurrence of monocotyledon species (Brachiaria mutica, Cynodon plectostachyus, Digitaria spp.), in treatments with less shade (maintained under banana trees with 5\% light restriction), followed by the other systems in increasing order of light restriction, coffee with Erythrina variegata and banana with $40 \%$ of shade, and coffee associated to banana Gliricidia sepium, with $86 \%$. In studies conducted in the same experimental area as the present study, Silva et al. (2006) observed behavior similar for adult weed plants. Both relative frequency and relative density of the monocotyledon plants were superior in the treatments conducted under direct sunlight, without the presence of grevilleas, with highest occurrence of Brachiaria brizanta and Rhynchelitrum repens, Panicum maximum, Cenchrus echinatus and Commelina benghalensis. Nestel \& Altieri (1992) verified that, under tree cover conditions, there was a greater occurrence of species from the Commelinaceae family, which has a characteristic of reduced capacity to compete with cultivated species. These authors verified the predominance of a species from the hyestes Poaceae and Compositae families with a higher capacity of growth under direct sunlight, making it an extremely aggressive competitor to the other species in the system. Under natural shade conditions, the decreased occurrence of Commelina benghalensis seeds in the present study was related to its capacity to emit partenocarpic fruit by subterranean rhizomes (rizantogens). Voll et al. (2002) verified that germination of canopy seeds of Commelina benghalensis L. is lower than root seeds, however, water absorption rates of both seed types were alike. According to Kissman $\&$ Kurt (2000), the vegetative propagules obtained from this fruit are larger than the seeds formed by flowers on the aerial part of the plant, and are able to emerge from $12 \mathrm{~cm}$. of depth. When seeds are formed on the aerial part of the plant, emergence does not occur at a depth greater than two $\mathrm{cm}$. As collection was conducted in the first $10 \mathrm{~cm}$ from the surface soil, the data obtained in this study do not express the real potential of this species propagation.

In contrast, the tests to discriminate seeds and seedling emergence in the present study demonstrated the incidence of species not verified in data collection on adult plants previously conducted by Silva et al. (2006). The emergence of these seeds was related to environmental greenhouse conditions, characterized by favorable humidity and sunlight. Souza (2003) verified the same behavior in a study on cupuaçu and wild palm (pupunha) plants in monoculture and agroforest system, where plants classified as monocotyledon benefited from more ample spacing of the single plantings. For the study cited, dicotyledons species predominated in agro forestry systems with a lower incidence of sunlight.

The comparison between shaded and sunlit coffee plantations resulted in a greater number of seeds and plantlets from dicotyledons species in soil from plantations associated with grevilea trees, the greatest number being: Amaranthus sp., Portulaca oleracea, Mollungo verticillata and Chenopodium caricatum, species better adapted to a lower incidence of sunlight as provided by the grevilea canopy (Tables 1 and 2). In studies on spatial distribution of floristic composition and 
functional types of species, according to the photosynthetic route (C3 and C4), Patta Pillar et al. (2002) verified that reduced radiation incidence on the inferior strata during the initial development of eucalyptus resulted in reduced cover with $\mathrm{C} 4$ species plants and increased frequency of the $\mathrm{C} 3$ species, more tolerant to shade.

The highest importance value indexes (IVI) were verified for the species Brachiaria sp., Portulaca oleracea, Mollungo verticillata, Amaranthus sp., in the seed test, and Portulaca oleracea, Chenopodium caricatum, Brachiaria sp. and Gnaphalium sp., in plantlet emergence. It was observed that the species with higher IVI have a high capacity of producing diaspora per plant, which permits intense infestation of the area.

The IVI values for the monocotyledon species were higher in the seed test (143.42 for sun and 104.1 for shade) when compared to emergence under greenhouse conditions. The IVI for emergence under greenhouse conditions was observed as 83.56 for soil from direct sunlight treatment and 75.63 for shade treatment. For the genus Gnaphalium sp., there were surges of emergence in some shaded treatments, mainly at the density of 139 plants ha $^{-1}$. However, when the average of shaded treatments was compared to the field

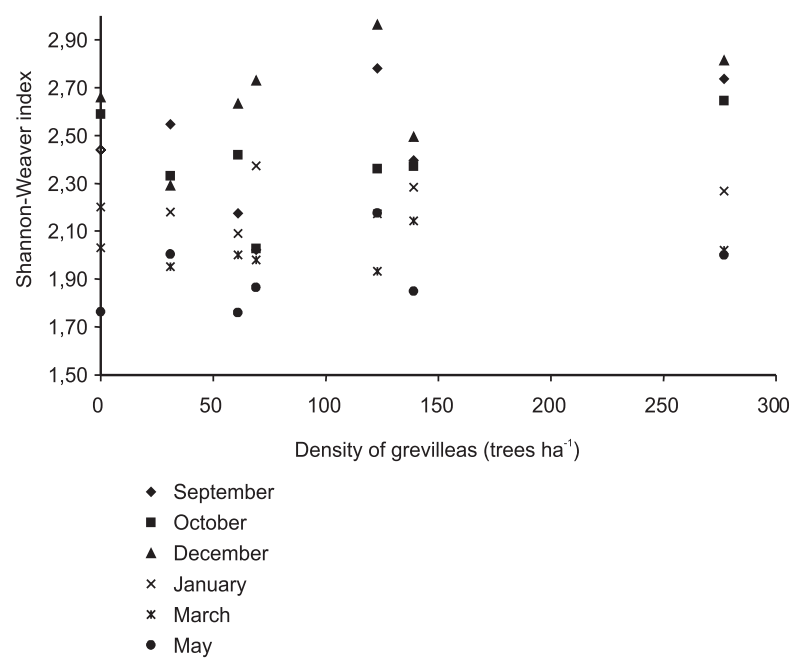

Figure 1 - Shannon-Weaver index of emergence test of weed seedlings originated from bank seed of coffee plantation (Coffea arabica L.) associated to different densities of grevillea trees and at full sunlight. Vitória da Conquista, Bahia. 2007. under direct sunlight, such effect was reduced. The percentage of emergence was lower for the monocotyledon species, indicating a possible dormancy due to hormonal alterations or to immaturity of the embryo of some species of the family Poaceae. Carvalho et al. (2002) conducted studies on the behavior of Poaceas species associated to red angico (Anadenanthera macrocarpa) and observed that natural shade retarded the beginning of flowering, and attributed the cause to more prolonged vegetative growth of plants under restricted light. Oliveira \& Humphreys (1986) verified that light restriction also reduces the production of seeds of the Poacea species, due to the reduced density of panicles per $\mathrm{m}^{2}$.

Analysis of the field data also demonstrated that there was a tendency of decreased emergence under greenhouse conditions in relation to the period of collecting soil samples. After a second collection (October), seed emergence under greenhouse conditions was reduced. Increased emergence under field conditions (data not shown) was one of the main factors related to this behavior, as it decreased the availability of seeds in the soil (when compared to emergence under greenhouse conditions). After the fourth collection, however, emergence increased

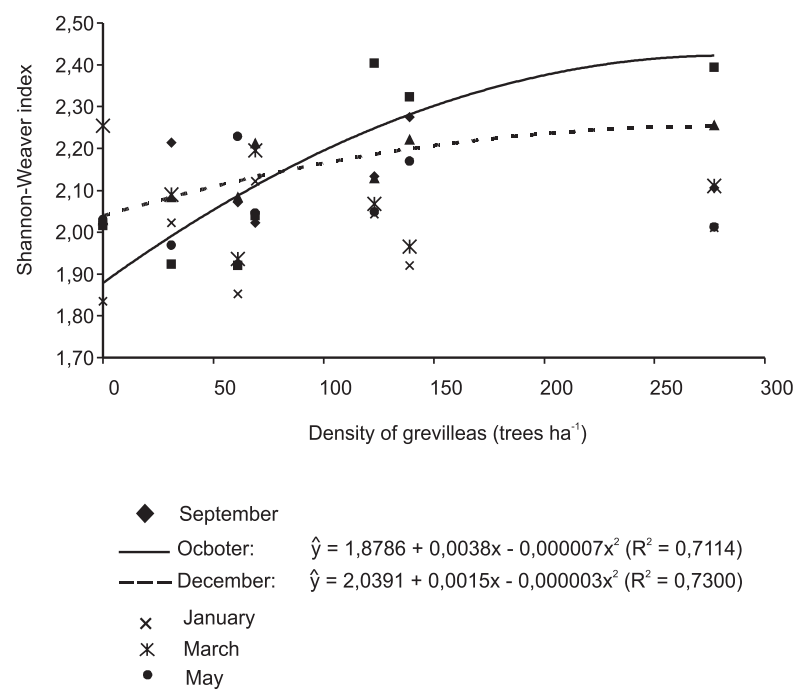

Figure 2 - Shannon-Weaver index of occurrence of weed seeds in coffee plantation soil (Coffea arabica) associated to different densities of grevillea trees and at full sunlight. Vitória da Conquista, Bahia. 2007

Planta Daninha, Viçosa-MG, v. 26, n. 4, p. 726-733, 2008 
again, probably due to maturation and posterior abscission of seeds from plants previously germinated in the field.

It was not possible to adjust models for the seedling emergence test when evaluating the relation between species diversity index (Shannon-Weaver) and the different grevillea densities (Figure1). For this test, the effect of the sampling phases was significant, as the highest values were observed in the first three months and the lowest in the last three months of sampling. For the seed test (Figure 2), this behavior was not observed, and the values were lower than in the results obtained in emergence under greenhouse conditions. Coelho et al. (2004) evaluated coffee plantations under three systems of cultivation and observed that the shade levels influenced the emergence of the species composing the seed bank. According to the authors, low levels of diversity were verified in the seedlings emerging from soils collected from $0.20 \mathrm{~m}$ extracts under greater levels of light restriction.

The diversity values of the seedling population that emerged from soil with different treatments were superior to those observed in the seed population (Figures 1 and 2), although there was a small variation during the sampling months. The environmental factors favorable under greenhouse conditions determined the uniform distribution in the plot emergence. Thus, there was a higher relative frequency that resulted in higher diversity index, notwithstanding the emergence of a lesser number of species, compared to the number of seeds.

Planting trees interferes in the composition of the soil's seed bank, principally in relative frequency, relative abundance and importance value index. The most significant effects of planting trees on these indexes were verified for the weed species classified as monocots, belonging to the family Poaceae, of highly competitive value for the coffee culture.

\section{LITERATURE CITED}

BUSELATO, T. C.; BUENO, O. L. Composição florística de dois campos localizados no município de Montenegro, Rio Grande do Sul, Brasil. Iheringia Ser. Bot., v. 26, n. 1, p. $65-84,1981$
CARVALHO, M. M.; FREITAS, V. P.; XAVIER, D. F. Início de florescimento, produção e valor nutritivo de gramíneas forrageiras tropicais sob condição de sombreamento natural. Pesq. Agropec. Bras., v. 37, n. 5, p. 717-722, 2002.

COELHO, R. A. et al. Influência do sombreamento com leguminosas arbóreas sobre a população de plantas espontâneas em área cultivada com cafeeiro (Coffea canephora). Agronomia, v. 38, n. 1, p. 23-29, 2004.

FAVRETO, R.; MEDEIROS, R. B. Banco de sementes de solo em área agrícola sob diferentes sistemas de manejo estabelecido sobre campo natural. R. Bras. Sementes, v. 28, n. 2, p. 34-44, 2006.

ISAAC, R.A.; GUIMARÃES, S.C. Banco de sementes e flora emergente de plantas daninhas. Planta Daninha, v. 26, n. 3, p. 521-530, 2008 .

KISSMANN, K. G.; KURT, D. Plantas infestantes e nocivas. São Paulo: BASF, 2000. 978 p

LACERDA, A. L. S. Fluxos de emergência e bando de sementes de plantas daninhas em sistemas de semeadura direta e convencional e curvas dose resposta ao glyphosate. 2003. $141 \mathrm{f}$. Tese (Doutorado em Agronomia) - Escola Superior de Agricultura "Luiz de Queiroz", Piracicaba, 2003.

LORENZI, H. Manual de identificação e controle de plantas daninhas, plantio direto e convencional. 4. ed. Nova Odessa: Plantarum, 1994. 440 p.

NESTEL, D.; ALTIERI, M. The weed community of Mexican coffee agro ecosystems: Effect of management upon plant biomass and species composition. Acta Ecol., v. 13, n. 6, p. 715-726, 1992

OLIVEIRA, P. R. P. ; HUMPHREYS, L. R. Influence of level and timing of shading on seed production in Panicum maximum cv. Gatton. Aust. J. Agricul. Res., Melbourne, v. 37, n. 4 , p. $417-424,1986$.

PATTA PILLAR, V.; BOLDRINI, I. I.; LANGE, O. Padrões de distribuição espacial de comunidades campestres sob plantio de eucalipto. Pesq. Agropec. Bras., v. 37, n. 6, p. $753-761,2002$

RONCHI, C.P.; SILVA, A.A. Efeitos da competição de plantas daninhas sobre o crescimento de plantas jovens de café. Planta Daninha, v. 24, n. 3, p. 415-423, 2006a.

RONCHI, C.P. et al. Crescimento e concentração de nutrientes no sistema radicular do cafeeiro sob competição de plantas daninhas. Planta Daninha, v. 25, n. 4, p. 679$687,2006 \mathrm{~b}$

SÁ, C. F. C. Regeneração em área de floresta de restinga na Reserva Ecológica Estadual de Jacarepiá, Saquarema, RJ: I Estrato herbáceo. Arq. Jard. Bot. Rio Janeiro, v. 34, n. 1, p. 177-192, 1996 
SEVERINO, F. J.; CHRISTOFFOLETI, P. J. Banco de sementes de plantas daninhas em solos cultivados com adubos verdes. Bragantia, v. 60, n. 3, p. 201-204, 2001.

SILVA, S. O. et al. Diversidade e freqüência de plantas daninhas em associações entre cafeeiros e grevíleas. Coffee Sci., v. 1, n. 2, p. 126-134, 2006.

SOUZA, L. S. A.; SILVA, J. F.; SOUZA, M. D. B

Composição florística de plantas daninhas em agrossistemas de cupuaçuzeiro (Theobroma grandiflorum) e pupunheira (Bactris gasipaes). Planta Daninha, v. 21, n. 2, p. 249-255, 2003.
SOUZA, L.S. et al. Efeitos das faixas de controle do capimbraquiária (Brachiaria decumbens) no desenvolvimento inicial e na produtividade do cafeeiro (Coffea arabica)

Planta Daninha, v. 24, n. 4, p. 715-720, 2006.

STAVER, C. et al. Designing pest-suppressive multistrata perennial crop systems: Shade-grown coffee in Central America. Agrofor. Syst., v. 53, n. 2, p. 151-170, 2001.

VOLL, E. et al. Aspectos fisiológicos da germinação de sementes de trapoeraba (Commelina benghalensis L.). R. Bras. Sementes, v. 24, n. 1, p. 162-168, 2002. 